\title{
Skaldic Panegyric and the Anglo-Saxon Chronicle Poem on the Redemption of the Five Boroughs
}

\author{
Leading Researcher Inna Matyushina \\ Russian State University for the Humanities \\ Miusskaya Ploshchad \\ korpus 6, Moscow \\ Russia, 125047 \\ Honorary Professor, University of Exeter \\ Queen's Building, The Queen's Drive \\ Streatham Campus, Exeter, EX4 4QJ
}

\begin{abstract}
Summary:
The paper attempts to reveal the affinities between skaldic panegyric poetry and the Anglo-Saxon Chronicle poem on the 'Redemption of the Five Boroughs' included into four manuscripts (Parker, Worcester and both Abingdon) for the year 942. The thirteen lines of the Chronicle poem are laden with toponyms and ethnonyms, prompting scholars to suggest that its main function is mnemonic. However comparison with skaldic drápur points to the communicative aim of the lists of toponyms and ethnonyms, whose function is to mark the restoration of the space defining the historical significance of Edmund's victory. The Chronicle poem unites the motifs of glory, spatial conquest and protection of land which are also present in Sighvat's Knútsdrápa (SkP I 660. 9. 1-8), bearing thematic, situational, structural and functional affinity with the former. Like that of Knútsdrápa, the function of the Chronicle poem is to glorify the ruler by formally reconstructing space. The poem, which, unlike most Anglo-Saxon poetry, is centred not on a past but on a contemporary event, is encomium regis, traditional for skaldic poetry. 'The Redemption of the Five Boroughs' can be called an Anglo-Saxon equivalent of erfidrápa, directed to posterity and ensuring eternal fame for the ruler who reconstructed the spatial identity of his kingdom.
\end{abstract}

Key words: Anglo-Saxon Chronicle, skaldic poetry, panegyric, toponym, ethnonym.

The theme of the poem in the Anglo-Saxon Chronicle, usually referred to by publishers as 'The Capture of the Five Boroughs' or 'The Redemption of the Five Boroughs', is connected with the victory of King Edmund, who had a glorious lineage: he was a grandson of King Alfred the Great, the son of King Edward the Elder and the brother of King Æthelstan. It is in connection with King Æthelstan that his name is mentioned in the most famous of the Chronicle poems, the 'Battle of Brunanburh' (937), where it is stated that Edmund was fighting alongside his illustrious brother Æthelstan, King of Wessex, and that both acquired eternal glory in the great battle. The reason why the poem on the battle of Brunanburh is included into four manuscripts of the Chronicle (the Parker, Worcester and both Abingdon manuscripts) is self-evident: it is because the victory of Athelstan and Edmund in this battle ensured that nearly the whole of England, not excluding the Danelaw, for the first time came under the rule of Wessex.

It is much harder to understand why the second poem, which mentions King Edmund (the poem on The Capture of the Five Boroughs), is also included into the same four manuscripts of the Chronicle. Like most of the Chronicle poems, it belongs to the genre of political poetry, whose development was examined by Professor Eric Stanley in his article 'A Thousand Years of English Political Poetry: A Limited Selection'. Of the two functions of political poetry, which were singled out by Professor Stanley, 'the satirical criticism of tyranny' and 'genuine or pretended delight and praise of the government ', it is closer to the latter, though it is hard to establish whether this delight is genuine or pretended. The poem on the Capture of the Five Boroughs, dated to the year 942, is dedicated to the victory over the Five Boroughs (the area of the modern north-eastern Midlands consisting of Leicester, Nottingham, Derby, Lincoln and Stamford). Nevertheless it does not mention the fact that in order to regain these lands, King Edmund had first to lose them ${ }^{2}$.

\footnotetext{
${ }^{1}$ Stanley E.G. A Thousand Years of English Political Poetry: A Limited Selection. Neophilologus, 2012. Vol. 96. P. 315 .

${ }^{2}$ Sources preserve little information about King Edmund, and scholars usually dismiss him, expressing opinions like: "Athelstan was succeeded by his brother Edmund, and he by his brother Eadred; both were conscientious monarchs
} 
The role of this poem in the Chronicle remains unclear, as it narrates a victory of the King who only managed to regain space he had lost, thus unwittingly attracting attention to his prior defeat.

Unlike the 'Battle of Brunanburh', which in the Chronicle precedes the poem on the Redemption of the Five Boroughs, the latter needs to be interpreted in its historical context, which can be partly reconstructed on the basis of the prose text of the Chronicle, as well as that of the 'Historia regum Anglorum' attributed to Simeon of Durham ${ }^{3}$. The Parker Chronicle tells us that Edmund was 18 when he ascended the throne, after the death of his brother Æthelstan in 939, but it conceals the fact that no sooner had he become King than he had to fight Óláfr Guðfriðarson (called Anlaf in the Chronicle), who was eager to revenge his defeat in the battle of Brunanburh.

The Worcester manuscript of the Chronicle states that the "Northumbrians had forgotten their promises and elected Olaf from Ireland as their King" ("Her Norðhymbra alugon hira getreowaða and Anlaf of Yrlande him to cinge gecuron"4). It is possible to assume that when Olaf got to know of Æthelstan's death, he left Ireland and invaded York. From York, Olaf went to Northampton but could not capture it, so took the Mercian town Tamworth. The Worcester Chronicle, dated 943 but relating the events of 940, mentions that 'Olaf took Tamworth and there were many people slain on both sides, and the Danes were victorious and took rich booty' (Her Anlaf abræc Tamewurpe, and micel wæl gefeol on ægpra hand, and pa Denan sige ahton, and micele herehupe mid him aweglæddon).

Having taken Tamworth, Olaf went north and invaded the territory of the Five Boroughs, where he became entrapped in Leicester, which was besieged by Edmund. The Worcester Chronicle enigmatically reports that 'King Edmund besieged King Olaf and Archbishop Wulfstan in Leicester and would have captured them had they not escaped from that town at night' (Her Eadmund cyning ymbsæt Anlaf cyning and Wulfstan arcebiscop on Legraceastre, and he hy gewyldan meahte, nære pæt hi on niht ut ne ætburston of pære byrig). As Olaf had to wait for the night to escape, it is likely that his troops had to stay in the besieged Leicester. That made Edmund's task more difficult as he had to free the town from Olaf's troops who remained in it. So it would have been in interests of both rulers to come to a peaceful agreement ${ }^{6}$. Yet in terms of space the distribution was far from equal: Olaf benefitted far more than Edmund, who had lost control over Northumbria and Mercia. Olaf, on the other hand, not only kept Dublin but had also acquired York, virtually the whole of the Danelaw, the Danish part of Mercia and the Five Boroughs (Leicester, Nottingham, Derby, Lincoln, Stamford $)^{7}$.

It is hard to imagine how a Wessex King could have agreed voluntarily to give up the heroic achievements of his ancestors in the acquisition of space: by his father (Edward the Elder) who had gained the whole of the southern part of the Danelaw in the great battles of 911-920, and by his brother Æthelstan, who had brought the territory of Northumbria and York under Wessex rule. Olaf managed to gain half of country through the peace treaty with the Wessex King without even having to bring many troops (as his kinsmen Ivarr and Halfdane had to do in 865). Norse domination over the British Isles had never been so great since Alfred the Great.

It is not clear who would have gained power over the whole country had Olaf not died suddenly the next year (in 941). The ruler of Dublin and York became his cousin Olaf Sigtryggsson, nicknamed Kváran. Exactly like Olaf Guðfriðarson, who had used Æthelstan's death to invade York, Edmund took advantage of the death of his enemy,

about whom comparatively little is known; neither lived long" (Christopher Brooke. The Saxon and Norman Kings. Glasgow: Fontana/Collins 1979, 125).

${ }^{3}$ This period of Anglo-Saxon history, including the reign of King Edmund, is usually considered to be one of the worst illuminated by the sources (cf. "The difficulty of distinguishing between Anlaf Guthfrithson and Anlaf Sihticson, and the impossibility of reconciling the conflicting dates supplied by the various manuscripts of the Chronicle, have combined to render this period, 938-46, one of the obscurest in our national annals." Murray Beaven. "King Edmund I and the Danes of York". English Historical Review 33/129, 1918, 1.

${ }^{4}$ The annals of the Anglo-Saxon Chronicle are quoted from: John Earle, Two of the Saxon Chronicles Parallel with Supplementary Extracts from the Others. Oxford: Clarendon Press, 1885.

${ }^{5}$ Alfred Smyth, Scandinavian York and Dublin. The History and Archaeology of Two Related Viking Kingdoms. Vol. II. New Jersey and Dublin, 1979, 92.

${ }^{6}$ Simeon of Durham points out that there was no great fighting in Leicester as two archbishops Odo and Wulfstan made the kings reconcile and put an end to their war (Thomas Arnold, "Historia regum Anglorum (sub anno 939)", Symeonis monachi opera omnia. Rolls Series 75, 2 vols. London: Edward Arnold, 1885, 94).

${ }^{7}$ As is stated by Simeon of Durham, the boundaries of each state were drawn along Watling Street. Edmund kept the southern part, whereas Olaf acquired the northern area (Arnold 94). 
invaded Mercia and brought the Five Boroughs back under Wessex rule. It was this reclamation of temporarily lost space that became the theme of the poem included into the Chronicle:

\begin{tabular}{|c|c|}
\hline $\begin{array}{l}\text { Her Eadmund cyning, Engla peoden, } \\
\text { mæcgea mundbora, Myrce geeode, } \\
\text { dyre dædfruma, swa Dor scadep, } \\
\text { Hwitanwyllesgeat and Humbra ea, } \\
\text { brada brimstream. Burga fife, } \\
\text { Ligoraceaster and Lincylene } \\
\text { and Snotingaham, swylce Stanford eac } \\
\text { and Deoraby. Dæne wæran æror } \\
\text { under Norðmannum nyde gebegde } \\
\text { on hæpenra hæfteclommum } \\
\text { lange prage, op hie alysde eft } \\
\text { for his weorbscipe wiggendra hleo, } \\
\text { afera Eadweardes, Eadmund cyning. }\end{array}$ & $\begin{array}{l}\text { Here King Edmund, lord of the English, } \\
\text { guardian of kinsmen, dear accomplisher of deeds, } \\
\text { conquered Mercia, restricted by the Dore, Whitwell } \\
\text { gap and Humber river, broad stream of the ocean. } \\
\text { Five boroughs: Leicester, and Lincoln, and } \\
\text { Nottingham, as well as Stamford and also Derby. } \\
\text { The Danes were earlier under Northmen, crushed } \\
\text { by force in heathens' captive fetters, for a long time } \\
\text { until they were set free again, to the honour of } \\
\text { Edward's son, defender of warriors, King Edmund. }\end{array}$ \\
\hline
\end{tabular}

The Redemption of the Five Boroughs is depicted by the creator of the poem as a crusade for the spiritual liberation of the enslaved population of Mercia. King Edmund is presented as a liberator who 'went through' (geeode), meaning 'conquered' and 'set free' (alysde) the Danes. Edmund is shown as an active hero: 'accomplisher of deeds' (dcedfruma), 'defender of warriors' (wiggendra hleo), 'guardian of kinsmen' (macgea mundbora), whereas the Danes are presented as passive subjects, bound by the fetters of heathendom. By going through Mercia (the verb gegan implies a spatial image), Edmund opens up the space to which the Danes were confined and becomes the protector and the guardian of the redeemed space.

Grammar in the poem faithfully serves semantics: the predicate in the passive voice (waran nyde gebegde, 'were subjected by force') follows the ethnonym 'the Danes' (Dane), which in the Parker manuscript ${ }^{9}$ performs the function of the subject: the Danes were crushed by force, waran nyde gebegde (in the Parker manuscript the participial form gebegde is used of the verb gebegan, 'to humble, crush, bow down') or were forced by the need, nede gebeded (in the Worcester and both Abingdon manuscripts, as well as in the Battle of Brunanburh ${ }^{10}$, the participle gebeded from the verb gebadan, 'to force, compel' is used) by the Norwegians (Norðmenn) to the fetters of heathendom. Thus in all the four manuscripts the idea of the passivity of the Danes is stressed albeit through contextually synonymous verbs (gebegan and gebadan).

The creator of the poem is distinguishing the Danes, the second or third generation of the Vikings who settled in the British Isles and adopted Christianity, from the Northmen (Norðmenn), heathens (hrepena), who invaded England together with Olaf Guðfriðarson ${ }^{11}$. The fourteen years of Æthelstan's rule must have caused the Danes in Eastern Mercia to consider themselves the lawful subjects of the Wessex ruler ${ }^{12}$. Though the poem undoubtedly expresses the Wessex point of view, its creator had reason to show the capture of the Five Boroughs as war against paganism, because the Vikings did ransack monasteries, starting with Lindisfarne, and Olaf Guðfriðarson's last deed was also

${ }^{8}$ The text of the poem on the Redemption of the Five Boroughs is quoted from Elliott Van Kirk Dobbie, The AngloSaxon Minor Poems, Volume 6 of The Anglo-Saxon Poetic Records, eds. George Philipp Krapp and Elliott Van Kirk Dobbie. New York: Columbia University Press, 1942, 20-21.

${ }^{9}$ In the Worcester manuscript the ethnonym denoting the Danes is used in the dative case (Denum) as a homogeneous component to another ethnonym "under the Norsemen" (under Norðmannum); the whole sentence then can be interpreted as "the Five Boroughs were formerly compelled to the fetters of heathendom by the Danes, the Norsemen". The arguments for the preference of the variant contained in the Parker manuscript, in which the ethnonym denoting the Danes is used in the nominative case (Dane), are discussed in the article by Mawer 1923: 551-557.

${ }^{10}$ It can be suggested that the creator of the poem consciously follows the model of the Battle of Brunanburh. It uses the same alliterative pattern as the Battle of Brunanburh (33): pær geflemed wearð // Norðmanna bregu, / nede gebeded, // to lides stefne / litle weorode, "There the ruler of Northmen, compelled by necessity, was put to flight, to ship's prow, with a small troop" (Translated by M.Swanton. The Anglo-Saxon Chronicles. New Edition. Translated and Edited by M.Swanton. London: Phoenix Press, 1996). The ruler of Northmen, whose flight is described in the quoted lines by the creator of the Battle of Brunanburh, is Óláfr Guðfriðarson, who could not possess the Five Boroughs for long.

${ }^{11}$ Mawer A. The Redemption of Five Boroughs. In: English Historical Review. Vol. 38. No. 152. 1923. P. 544-555.

${ }^{12}$ Stenton F. Anglo-Saxon England. Oxford: Oxford University Press, 1985. P. 354. 
heathen: according to Simeon of Durham, he 'ransacked the Church of Saint Bealdhere and burned Tinnigham. Then the people of York plundered the Isle of Lindisfarne and killed many people ${ }^{, 13}$.

As in the Anglo-Saxon poem on the Redemption of the Five Boroughs, the struggle against the enemy is presented in the tradition of skaldic poetry which coexists with $i^{14}$ as a campaign against heathendom. In his poems composed for King Magnus the Good ('Hrynhenda') Arnor Jarlaskald states that the King (Magnus the Good) was burning heathens in Jóm (heiðit folk B I 309, 12), and in the memorial poem (erfidrápa) by the same skald on King Magnus it is said that the flames consumed the unbaptised heads of the fallen (óskirð enni B I 313, 8). As is stated in Ólafs saga helga (chapter 91), Sigvatr Pórðarson, in 'Austrfararvísur', also shows the hostile behaviour of the pagans in Sweden, who were holding the Álfablót (elven sacrifice) and did not want to let him in, which is why he cursed them:

\begin{tabular}{|c|c|c|}
\hline $\begin{array}{l}\text { Sigvatr Pórðarson } \\
\text { (SkP II, 589), } \\
\text { Austrfararvísur }\end{array}$ & $\begin{array}{l}\text { Réðk til Hofs at hœfa; } \\
\text { hurð vas aptr, en spurðumk } \\
\text { — inn settak nef nenninn } \\
\text { niðrlútt - fyrir útan. } \\
\text { Orð gatk fæst af fyrðum, } \\
\text { (flogð baðk) en pau sogðu } \\
\text { — hnekkðumk heiðnir rekkar — } \\
\text { heilagt (við pau deila). }\end{array}$ & $\begin{array}{l}\text { I resolved to aim for Hof; the door was barred, but I } \\
\text { made enquiries from outside; resolute, I stuck my } \\
\text { down-bent nose in. I got very little response from the } \\
\text { people, but they said [it was] holy; the heathen men } \\
\text { drove me off; I bade the ogresses bandy words with } \\
\text { them. } \\
\text { (Translated Robert D. Fulk) }\end{array}$ \\
\hline $\begin{array}{l}\text { Sigvatr Pórðarson } \\
\text { (SkP II, 590), } \\
\text { Austrfararvísur }\end{array}$ & $\begin{array}{l}\text { Gakkat inn,' kvað ekkja, } \\
\text { 'armi drengr, en lengra; } \\
\text { hræðumk ek við Óðins } \\
\text { — erum heiðin vér - reiði.' } \\
\text { Rýgr kvazk inni eiga } \\
\text { ópekk, sús mér hnekkði, } \\
\text { alfablót, sem ulfi } \\
\text { ótvín, í bœ sínum }{ }^{15} \text {. }\end{array}$ & $\begin{array}{l}\text { "Do not come any further in, wretched fellow', said } \\
\text { the woman; 'I fear the wrath of Óðinn; we are } \\
\text { heathen.' The disagreeable female, who drove me } \\
\text { away like a wolf without hesitation, said they were } \\
\text { holding a sacrifice to the elves inside her farmhouse" } \\
\text { (Translated Robert D. Fulk). }\end{array}$ \\
\hline
\end{tabular}

In the poem on the recapture of the five boroughs there are other features, bringing it close to skaldic poetry, which is famous for its highly developed capacity for formal variation of nominations of key objects ${ }^{16}$. In the Anglo-Saxon poem, as in skaldic poetry, the dominant position is given to denotations for the ruler: in the thirteen lines of the poem there are seven different phrases used to refer to King Edmund.

These appellations are built according to models which were productive in skaldic poetry. For example, the model underlying the word-combination 'the ruler of the Angles', Engla peoden is widely spread in skaldic panegyrics (cf. ' the King of the Hǫrðar', people of Hordaland, Horða konungr BI 119, 13 in Einarr Helgason skálaglamm's Vellekla; 'the prince of the Jutes', Jóta gramr, 'the ruler of the Hǫrðar', Horða dróttinn BI 306, 1 in the drápa for Magnus the Good Hrynhenda by Arnórr Pórðarson jarlaskáld) ${ }^{17}$.

Other designations of the ruler used in the Anglo-Saxon poem are similar to skaldic periphrastic denotations of a King or ruler. Thus the word-combinations 'protector of warriors', wiggendra hleo and 'guardian of kinsmen', maecgea mundbora (both are used of Edmund), can be compared with the denotations of the King as 'the guardian, protector of

\footnotetext{
${ }^{13}$ Arnold, Thomas, Symeonis monachi opera omnia. Rolls Series 75. London: Edward Arnold, 1885. P. 94.

${ }^{14}$ The only Chronicle poem which has been hitherto compared with skaldic poetry is the Battle of Brunanburh: Opland J. Anglo-Saxon Oral Poetry: A Study of the Traditions. New Haven and London: Yale University Press, 1980, P. 172; Lapidge M. Some Latin Poems as Evidence for the reign of Athelstan. In: Anglo-Saxon England, 9, 1981, P. 61-98; Harris J. Die altenglische Heldendichtung. In: Europäisches Frühmettelalter. Klaus von See (Herausgeg.) Neues Handbuch der Literaturwissenschaft 6. Wiesbaden: : Aula, 1985. P. 248-254.

15 The text of Sigvatr Pórðarson's 'Austrfararvísur', and translations by Robert D.Fulk and others, unless otherwise stated, are quoted from: Skaldic Poetry of the Scandinavian Middle Ages: A New Edition, eds. Kari Ellen Gade, Diana Whaley. Vol. 1. Brepols, 2012.

${ }^{16}$ Smirnitskaya O.A. Verse and Language of Medieval Germanic Poetry (Stikh i yazyk drevnegermanskoy poesii). Moscow: Moscow State University, 1994. Vol. 2. P. 393.

${ }^{17}$ Quotations of skaldic poetry, unless otherwise stated, are taken from: Finnur Jónsson, Den norsk-islandske Skjaldedigtning København, 1912-1915, København, 1967-1973. 
people', folk vorðr in Einarr Skúlason's drápa (B I 452, 2) or as 'the guardian, protector of land', grundar vorðr (B I $66,4)$ in Gráfeldardrápa, a memorial poem on Harald the Greyhide by Glúmr Geirason.

The effect of accumulating denotations of the ruler is to focus attention on what he has achieved: honorific titles indicate that the king has successfully protected the space he is responsible for. The denotation of the ruler as dyre daedfruma, 'dear accomplisher of deeds', brings to mind the Old Norse kenning with the same first component: frumsmiðr bragar, 'the first smith of poetry' denoting Bragi, the first poet and the god of poetry in Snorra Edda. The Anglo-Saxon poem's reference to the ruler as 'dear accomplisher of deeds' can also be compared to skaldic poems in its use of the epithet 'dear', which occurs in numerous skaldic panegyrics:

\begin{tabular}{|c|c|c|}
\hline $\begin{array}{l}\text { Eyvindr skáldaspillir } \\
\text { (SkP I, 229), Haralds } \\
\text { saga Gráfeldar } 1\end{array}$ & $\begin{array}{l}\text { Einn drottin hefk áttan, } \\
\text { jofur dýrr, an pik fyrra, } \\
\text { bellir, bragningr, elli, } \\
\text { biðkat mér ins priðja. } \\
\text { Trúr vask tyggja dýrum; } \\
\text { tveim skjoldum lékk aldri; } \\
\text { fyllik flokk pinn, stillir; } \\
\text { fellr á hendr mér elli }{ }^{18} \text {. }\end{array}$ & $\begin{array}{l}\text { I have had one lord before you, dear king; old } \\
\text { age presses, prince; I do not ask for a third for } \\
\text { myself. } \\
\text { I was true to the prized leader; I never played } \\
\text { with two shields; } \\
\text { I fill up your following, ruler; } \\
\text { old age descends on me. } \\
\text { (Transl. R.Poole) }^{19}\end{array}$ \\
\hline $\begin{array}{l}\text { Hallfreðr vandræðaskáld } \\
\text { 'Erfidrápa }\end{array}$ & $\begin{array}{l}\text { Sukku niðr af Naðri, } \\
\text { naddfárs í boðð sárir, } \\
\text { baugs - gerðut við vægjast - } \\
\text { verkendr meginserkjar. } \\
\text { Vanr mun Ormr, bótt Ormi } \\
\text { alldýr konungr stýri, } \\
\text { hvars skríðr með lið lýða, } \\
\text { lengi slíkra drengja. }\end{array}$ & $\begin{array}{l}\text { Wounded workers of the mighty shirt of the ring } \\
\text { of point-harm [BATTLE }>\text { SHIELD }>\text { MAIL- } \\
\text { SHIRT }>\text { WARRIORS] sank down off Naðr } \\
\text { ('Adder') in battle; } \\
\text { they did not yield. Ormr (Serpent) will long lack } \\
\text { such warriors, wherever it glides with the } \\
\text { company of men, though a very eminent (very } \\
\text { dear) King may command Ormr. (Translated } \\
\text { D.Whaley) }\end{array}$ \\
\hline
\end{tabular}

The Anglo-Saxon poem referring to the ruler as 'dear accomplisher of deeds' is similar to skaldic poems in the use of the base word meaning 'accomplisher' (viðr, 'the one who accomplishes'). This base word meaning 'accomplisher' is used as part of kennings of man in Snorra Edda: Svá, at kalla hann vinnanda eða fremjanda fara sinna eða athafnar, víga eða sæfara eða veiða eða vápna eða skipa - 'Thus, by calling him accomplisher or performer of his goings or his conduct, of his battles or sea-voyages or huntings or weapons or ships'. Like the King in the Anglo-Saxon poem, who has accomplished the acquisition of space, the King in skaldic poetry is essentially an active character, performing deeds and winning battles.

As in the Anglo-Saxon poem, in skaldic poetry we find designation of the ruler in terms of dynasty. The Anglo-Saxon denotation of Edmund as 'Edward's son (or heir)', afera Eadweardes, finds parallels in the following skaldic denotations: in the denotation of Glumr Geirason as 'Geiri's heir', arfvorðr Geiri (BI 541, 11), used in Íslendingadrápa by Haukr Valdísarson; of Canute as 'Svein's son', Sveins sonr (B I 303, 3), used in the memorial poem (erfidrápa) about Saint Olafr by Pórðr Sjáreksson; and in the denotation 'Tryggvi's son', Tryggva sonr B I 149, 6, in the Erfidrápa Óláfs Tryggvasonar by Hallfreðr vandræðaskáld. Like the skalds, who varied kennings according to established models inherited from their poetic tradition, the creator of the Anglo-Saxon poem builds his designations of the ruler according to the tradition he had inherited.

In the Anglo-Saxon Chronicle poem, variations in the denotations of the ruler, indicating what he has already accomplished and defining his status through the space he had regained, take the place of a narrative development of the theme. Like a skaldic visa, with its communicative deficiency caused by the hypertrophic form, the Anglo-Saxon poem contains only the announcement of the heroic deed and its evaluation. As in skaldic visas, which contain not a narration of events in linear succession but rather a register of actions, the subject of the Anglo-Saxon poem is a statement of fact, not a narration of the course of the battle or of the courage or other virtues of the hero (as in other Chronicle poems). All of these are implied symptomatically by simply mentioning the accomplished deeds of King Edmund (he conquered Mercia, he freed the Danes). The absence of linear narration in the poem is manifested in the scarcity of finite verbal forms, two of which (geode, 'went' and alysde, 'set free') refer to King Edmund.

\footnotetext{
${ }^{18}$ The text of skaldic poetry is quoted from Gade, Whaley 2009-2012.

${ }^{19}$ The translations of skaldic poetry, unless otherwise stated, are quoted from Gade, Whaley 2009-2012.
} 
As in skaldic verse, verbs in the poem are so colourless and lacking in information ${ }^{20}$, that they are close to functional verbs. They focus attention not on a narrative sequence in time but on the other dimension: space, acquired and protected.

Verbal forms (geode, scadep, gebegde) occupy the fourth (the least important) position in the line and only one is put in the position of key alliteration (alysde), when the verb becomes the thematic centre of the whole poem. On the contrary, compound words (mundbora, dadfruma, brimstream, haefteclommum, weorpscipe), proper names (Eadmund, Eadweardes), toponyms (Myrce, Dor, Hwitanwyllesgeat, Humbra, Ligoraceaster, Lincylene, Snotingaham, Deoraby), ethnonyms (Engla, Dane, Norðmannum) are always marked by alliteration, creating double alliterative patterns in four lines (macgea mundbora, dyre dadfruma, brada brimstream, afera Eadweardes), and crossed alliteration in one of the lines (Ligoraceaster and Lincylene), where alliteration underlines the importance of the spatial extent of the realm Edmund managed to redeem.

The abundance of names in the poem (fifteen names in thirteen lines: eight toponyms: Dor, Hwitanwyllesgeat, Humbra, Ligoraceaster, Lincylene, Snotingaham, Stanford, Deoraby; three proper names: Eadmund 1a, 13b, Eadweard 13a; four ethnonyms: Engle, Myrce, Dane, Norðmenn), gave grounds to scholars for suggesting that the poem has a mnemonic function ${ }^{21}$. However, it is possible to make a different suggestion based on comparison with skaldic panegyric poetry, which is also abundant in proper names and lists of toponyms, e.g.:

\begin{tabular}{|c|c|c|}
\hline $\begin{array}{l}\text { Arnórr } \quad \text { jarlaskáld } \\
\text { Pórðarson } \\
\text { (SkP II, 257), Óláfs saga } \\
\text { Helga, 103. }\end{array}$ & $\begin{array}{l}\text { Hringstríði varð hlýða } \\
\text { herr frá Pursaskerjum } \\
\text { - rétt segik pjóð, hve pótti } \\
\text { Porfinnr - til Dyflinnar. }\end{array}$ & $\begin{array}{l}\text { People had to heed the ring-harmer } \\
\text { [GENEROUS RULER] from Pursasker to } \\
\text { Dublin; I tell men truly how Porfinnr was } \\
\text { regarded. (Trans. D. Whaley) }\end{array}$ \\
\hline $\begin{array}{l}\text { Einarr } \\
\text { 'Vellekla' (SkPálaglamm } \\
\text { Ólafs saga } \\
\text { 18. }\end{array}$ & $\begin{array}{l}\text { Hitt var meir, at Mœra } \\
\text { morðfíkinn lét norðan } \\
\text { fólkverjandi fyrva } \\
\text { fơr til Sogns um gorva. } \\
\text { Ýtti Freyr af fjórum } \\
\text { fólklọndum - sá branda } \\
\text { Ullr stóð á pví allri } \\
\text { yrpjóð - Héðins byrjar }\end{array}$ & $\begin{array}{l}\text { It also happened that the battle-eager people- } \\
\text { defender of the Mœrir [NORWEGIAN } \\
\text { RULER = HÁKON JARL] had his men } \\
\text { undertake a journey from the north to Sogn. } \\
\text { The Freyr <god> of the wind of Heðinn } \\
\text { <legendary hero> [BATTLE> WARRIOR] } \\
\text { set out from four fólklond (Trøndelag, Møre, } \\
\text { Romsdalen, Hålogaland); that Ullr <god> of } \\
\text { swords [WARRIOR] thereby helped the } \\
\text { whole people. (Trans. E.Marold) }\end{array}$ \\
\hline
\end{tabular}

Like the Anglo-Saxon poem, skaldic poetry includes ethnonyms, among which both the Norsemen and the Danes are also mentioned:

\begin{tabular}{|c|c|c|}
\hline $\begin{array}{l}\text { Eyvindr Finnsson Skáldaspillir } \\
\text { 'Hákonarmál' (SkP I, 177), } \\
\text { Hákonar saga Góða, 30. }\end{array}$ & $\begin{array}{l}\text { Hét á Háleygi } \\
\text { sems á Hólmrygi } \\
\text { jarla einbani; } \\
\text { fór til orustu. } \\
\text { Gótt hafði hinn gjǫfli } \\
\text { gengi Norðmanna } \\
\text { œgir Eydana, } \\
\text { stóð und árhjálmi. }\end{array}$ & $\begin{array}{l}\text { The sole slayer of jarls [= Hákon] } \\
\text { called on the Háleygir (i.e. the inhabitants of Hálogaland) just } \\
\text { as on the Holmrygir, (i.e. the inhabitants of Rogaland); he } \\
\text { went into battle. } \\
\text { The munificent terrifier of island-Danes [= Hákon] had the } \\
\text { good support of the Norwegians; he stood under a helmet of } \\
\text { metal. } \\
\text { (Transl. R.D.Fulk) }\end{array}$ \\
\hline $\begin{array}{l}\text { Einarr skálaglamm 'Vellekla' } \\
\text { (SkP I, 314), Ólafs saga } \\
\text { Tryggvasonar, } 26\end{array}$ & $\begin{array}{l}\text { Hitt vas auk, at eykir } \\
\text { aurborðs á vit norðan } \\
\text { und sigrunni svinnum } \\
\text { sunnr Danmarkar runnu. } \\
\text { Ok hólmfjǫturs hjálmi } \\
\text { Họrða valdr um faldinn, } \\
\text { Dofra danskra jọfra, } \\
\text { dróttinn fund um sótti. }\end{array}$ & $\begin{array}{l}\text { It also happened that the draught-animals of the plank [SHIPS] } \\
\text { ran from the north under the wise victory-tree [WARRIOR] } \\
\text { south towards Denmark. And the ruler of the Horðar (i.e. the } \\
\text { inhabitants of Horthaland) [NORWEGIAN RULER = Hákon } \\
\text { jarl], the lord of the Dofrar [NORWEGIAN RULER = Hákon } \\
\text { jarl], wearing the helmet of the island-fetter [Miðgarðsormr], } \\
\text { sought a meeting with the Danish rulers. } \\
\text { (Transl. E.Marold) }\end{array}$ \\
\hline
\end{tabular}

\footnotetext{
${ }^{20}$ Lee Hollander, "The Role of Verb in Skaldic Poetry", Acta Philologica Scandinavica 20 (1949) 267-276.

21 Katherine O’Brien O'Keefe, Visible Song: Transitional Literacy in Old English Verse. Cambridge: Cambridge University Press, 1990, 123. 
In the Anglo-Saxon poem, as in skaldic panegyrics, toponyms, ethnonyms and proper names carry important communicative functions: they transform a report on a conventional battle into a report of a historical event. It is also possible to suggest that the same function is given to numerals in both skaldic panegyrics and the Anglo-Saxon poem. The mentioning of the 'five boroughs', burga fife, in the Anglo-Saxon poem is functionally equivalent to the lists of conquered areas, constituting newly acquired space, accompanied by numerals in skaldic poetry as illustrated below:

\begin{tabular}{|c|c|c|}
\hline 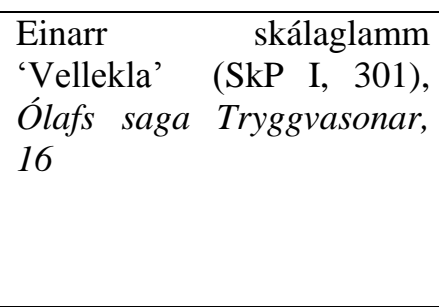 & $\begin{array}{l}\text { Sjau fylkjum kom silkis, } \\
\text { (snúnaðr var pat) brúna } \\
\text { geymir grundar síma } \\
\text { grandvar und sig (landi). }\end{array}$ & $\begin{array}{l}\text { The damage-wary keeper of the } \\
\text { silken band of the land of the brows } \\
\text { [HEAD > HEADBAND >RULER] } \\
\text { brought seven fylki under himself; } \\
\text { that was a change for the better for } \\
\text { the land. } \\
\text { (Transl. E.Marold) }\end{array}$ \\
\hline $\begin{array}{l}\text { Einarr } \\
\text { 'Vellekla' } \\
\text { (SkP I, 308), Ólafs saga } \\
\text { Tryggvasonar, 18 }\end{array}$ & $\begin{array}{l}\text { Ýtti Freyr af fjórum } \\
\text { fólklǫndum - sá branda } \\
\text { Ullr stód á pví allri } \\
\text { yrbjóð - Héðins byrjar. }\end{array}$ & $\begin{array}{l}\text { The Freyr <god }>\text { of the wind of } \\
\text { Heðinn <legendary hero> [BATTLE } \\
>\text { WARRIOR] set out from four } \\
\text { folklond; that Ullr }<\text { god }>\text { of swords } \\
\text { [WARRIOR] thereby helped the } \\
\text { whole people. } \\
\text { (Transl. E.Marold) }\end{array}$ \\
\hline
\end{tabular}

The use of numerals, proper and dynastic names, toponyms (conquered lands) and ethnonyms (liberated nations) individualises the situation and honours the ruler by listing the spatial extent of his realm, which is likely to be the main function of the Anglo-Saxon poem. A comparison with skaldic drápur thus points to a communicative aim in the lists of toponyms and ethnonyms, whose function here is to mark the extent of reclaimed space epitomizing the historical significance of Edmund's victory.

The motif of glory, explicitly present in the Anglo-Saxon poem (Edmund is constructing space 'for his glory', for his weorpscipe), belongs to topic motifs endlessly occurring in skaldic drápur. The king's glory is mentioned in Einarr skálaglamm's 'Vellekla':

\begin{tabular}{|c|c|c|}
\hline $\begin{array}{l}\text { Einarr skálaglamm } \\
\text { 'Vellekla' (SkP I, 297), } \\
\text { Haralds Saga } \\
\text { Gráfeldar, } 15\end{array}$ & $\begin{array}{l}\text { Hjálmgrápi vann hilmir } \\
\text { harðr (Lofts vinar) barða } \\
\text { (pví kom voxtr í Vínu } \\
\text { vínheims) fjandr sína. } \\
\text { Ok forsnjallir fellu } \\
\text { fúrs í Próttar skúrum, } \\
\text { (pat fær pjóðar snytri) } \\
\text { prír jarls synir (tírar). }\end{array}$ & $\begin{array}{l}\text { The hardy ruler had his enemies pelted with } \\
\text { helmet-hail [BATTLE]; therefore, growth } \\
\text { came to the Vína <river> of the wine-world } \\
\text { of the friend of Loptr <= Loki> [=Óðinn > } \\
\text { VAT > POEM]. And three exceedingly } \\
\text { brave sons of a jarl fell in showers of the } \\
\text { fire of Próttr [SWORD > BATTLE]; that } \\
\text { brings glory to the instructor of the people } \\
\text { [RULER = Hákon jarl]. (Transl. E.Marold) }\end{array}$ \\
\hline $\begin{array}{l}\text { Hallfreðr } \\
\text { vandræðaskáld } \\
\text { 'Óláfsdrápa' (SkP I, } \\
\text { 398), Ólafs saga } \\
\text { Tryggvasonar, } 30 \\
\end{array}$ & $\begin{array}{l}\text { Ýdrógar lét œgir } \\
\text { eyverskan her deyja } \\
\text { - Týr var tjorva dýrra } \\
\text { tírargjarn — ok Íra. }\end{array}$ & $\begin{array}{l}\text { The terrifier of the bow-string [WARRIOR] } \\
\text { caused the army from the Isles and the Irish } \\
\text { to die; the Týr <god> of precious spears } \\
\text { [WARRIOR] was eager for glory. } \\
\text { (Transl. D.Whaley) }\end{array}$ \\
\hline $\begin{array}{l}\text { Glúmr Geirason } \\
\text { 'Gráfeldardrápa' } \quad \text { (SkP } \\
\text { I, 255), Haralds Saga } \\
\text { Gráfeldar, } 14\end{array}$ & $\begin{array}{l}\text { Austr rauð jöfra prýstir } \\
\text { orðrakkr fyr bý norðan } \\
\text { brand, par er bjarmskar kindir, } \\
\text { brinnanda, sák rinna. } \\
\text { Gótt hlaut gumna sæettir, } \\
\text { (geirveðr) í for beiri, } \\
\text { (oðlingi fékkst ungum), } \\
\text { orð (á Vínu borði). }\end{array}$ & $\begin{array}{l}\text { The word-bold crusher of princes [KING = } \\
\text { Haraldr] reddened the flashing sword in the } \\
\text { east, north of the settlement, where I saw } \\
\text { Permian people flee. The reconciler of men } \\
\text { [KING = Haraldr] gained a good reputation } \\
\text { on that expedition; a spear-storm } \\
\text { [BATTLE] was granted to the young prince } \\
\text { on the banks of the Dvina. (Transl. } \\
\text { A.Finlay) }\end{array}$ \\
\hline
\end{tabular}


The motif of glory is intertwined in the Anglo-Saxon poem with the motif of spatial conquest (Edmund conquered Mercia, Myrce geeode), which is also a favourite topos of skaldic panegyrics:

\begin{tabular}{|c|c|c|}
\hline 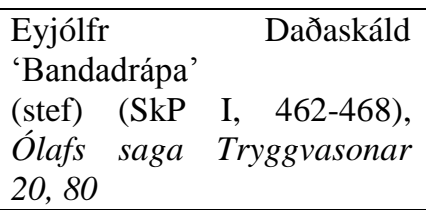 & $\begin{array}{l}\text { Dregr land at mun banda (line } 8 \\
\text { of v. } 117) \ldots \\
\text { Eirekr und sik geira (line } 4 \text { of vv. } \\
149,152) \ldots\end{array}$ & $\begin{array}{l}\text { Wins land at the pleasure of the gods... } \\
\text { Eiríkr under himself of spears ... } \\
\text { (Transl. R.Poole) }\end{array}$ \\
\hline $\begin{array}{l}\text { Glúmr } \\
\text { 'Gráfeldardrápa' } \quad \text { Geirason } \\
\text { 253), Hákonar saga Góða, } \\
10\end{array}$ & $\begin{array}{l}\text { Austrlǫndum fórsk undir } \\
\text { allvaldr, sás gaf skọldum, } \\
\text { - hann fékk gagn at gunni - } \\
\text { gunnhọrga slọg mọrgum. } \\
\text { Slíðrtungur lét syngva } \\
\text { sverðleiks reginn - ferðir } \\
\text { sendi gramr að grundu } \\
\text { gullvarpaða snarpar. }\end{array}$ & $\begin{array}{l}\text { The mighty ruler, who gave many poets strikers of } \\
\text { battle-temples [SHIELDS > WEAPONS], subdued } \\
\text { eastern lands; he gained success in war. The god of } \\
\text { sword-play [BATTLE > WARRIOR] made keen } \\
\text { scabbard-tongues [SWORDS] sing; the prince sent } \\
\text { troops of gold-throwers [GENEROUS MEN] to the } \\
\text { ground. (Transl. A.Finlay) }\end{array}$ \\
\hline 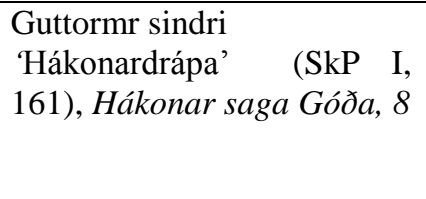 & $\begin{array}{l}\text { Selund náđi pá síðan } \\
\text { sóknheggr und sik leggja, } \\
\text { vals og Vinða frelsi } \\
\text { við Skáneyjar síðu. }\end{array}$ & $\begin{array}{l}\text { The attack-cherry-tree [WARRIOR = Hákon] then } \\
\text { afterwards succeeded in placing under himself } \\
\text { Zealand, the broad sanctuaries against slaughter and } \\
\text { the Wends, [and] the coast of Skåne. } \\
\text { (Transl. R.Poole) }\end{array}$ \\
\hline
\end{tabular}

The motif of spatial conquest is similarly intertwined in the Anglo-Saxon poem with the motif of protecting land which is equally important for skaldic panegyrics:

\begin{tabular}{|c|c|c|}
\hline $\begin{array}{l}\text { Haukr } \text { Valdísarsonar } \\
\text { 'Islendingadrápa' (9) }\end{array}$ & $\begin{array}{lccc}\text { Vọrðu } & \text { hauðr } & \text { pás, } & \text { hôðu } \\
\text { hlýrar tveir, } & \text { með } & \text { dýrum } \\
\text { foldar } & \text { vọrð } & \text { ok } & \text { fyrða, } \\
\text { fleinglygg, } & \text { Aðalsteini } & \\
\end{array}$ & $\begin{array}{l}\text { Two brothers were fighting, when they protected } \\
\text { land with Athelstan; worthy guards of land and } \\
\text { men. }\end{array}$ \\
\hline 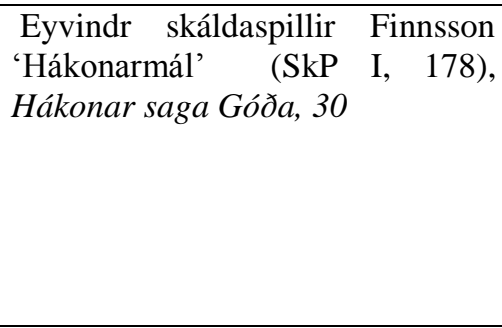 & $\begin{array}{l}\text { Hrauzk ór hervóðum, } \\
\text { hratt á voll brynju } \\
\text { vísi verðungar, } \\
\text { áðr til vígs tœki. } \\
\text { Lék við ljóðmǫgu, } \\
\text { - skyldi land verja - } \\
\text { gramr inn glaðværi; } \\
\text { stóð und gollhjálmi. }\end{array}$ & $\begin{array}{l}\text { The leader of the retinue [Hákon] threw off his } \\
\text { war-garments [ARMOUR], cast his mail-shirt to } \\
\text { the ground, before beginning the battle. The } \\
\text { cheerful ruler joked with his men; he had to } \\
\text { protect the land; } \\
\text { he stood under a golden helmet. } \\
\text { (Trans. R.D.Fulk) }\end{array}$ \\
\hline $\begin{array}{l}\text { Pórðr Kolbeinsson } \\
\text { 'Eiríksdrápa' (SkP I, 503), Ólafs } \\
\text { saga Tryggvasonar, 113 }\end{array}$ & $\begin{array}{l}\text { Allvalds nutu aldir; } \\
\text { una líkar vel slíku; } \\
\text { skyldr lézk hendi at halda } \\
\text { hann of Nóregs mǫnnum. } \\
\text { En Sveinn konungr sunnan } \\
\text { sagðr es dauðr, en auðir, } \\
\text { - fátt bilar flestra ýta } \\
\text { fár — hans býir vọ́ru. }\end{array}$ & $\begin{array}{l}\text { Men benefitted from the mighty ruler; it is most } \\
\text { pleasing to be content with such a situation; he } \\
\text { declared himself obliged to hold a hand over the } \\
\text { people of Norway. But King Sveinn is reported } \\
\text { from the south to be dead, and his dwellings to } \\
\text { have been desolate; misfortune scarcely spares } \\
\text { most men. } \\
\text { (Trans. J.Carroll) }\end{array}$ \\
\hline
\end{tabular}

All three motifs (those of glory, spatial conquest and spatial protection) are united in Sigvatr's Knútsdrápa, which bears the greatest situational, semantic, structural and functional affinities with the Anglo-Saxon poem:

\begin{tabular}{|c|c|c|}
\hline $\begin{array}{l}\text { Sigvatr } \\
\text { 'Knútsdrápa' (SkP I 660. } 9 . \\
\text { 1-8), Óláfs saga Helga, } 149\end{array}$ & $\begin{array}{l}\text { Létat af jǫfurr } \\
\text { (ætt manna fansk) } \\
\text { Jótlands etask } \\
\text { ílendr (at pví). } \\
\text { Vildi foldar } \\
\text { fæst rón Dana } \\
\text { hlífskjǫldr hafa } \\
\text { hofuðfremstr jofurr. }\end{array}$ & $\begin{array}{l}\text { Arrived in his land, the lord of Jutland [DANISH } \\
\text { KING = Knútr] did not let himself be deprived; the } \\
\text { race of men were pleased at that. The protecting } \\
\text { shield of the Danes [DANISH KING = Knútr] would } \\
\text { allow minimal plundering of the land. The most } \\
\text { eminent prince. } \\
\text { (Transl. M.Townend) }\end{array}$ \\
\hline
\end{tabular}


Both the Anglo-Saxon poem on the Five Boroughs and a skaldic visa consist of two syntactically independent units. Both use ring composition: Sigvatr starts and concludes with the denotation of the ruler, jofurr; the Anglo-Saxon poem starts and concludes with a reference to King Edmund, Eadmund cyning). In both, narrative details are omitted, and actions are compressed through asyndetic constructions, increasing the effect of simultaneity; in both, the communicative area is narrowed under the pressure of formal markers, such as toponyms and ethnonyms; in both, events are reported for the sake of augmenting the value of the victories. Both poems contain several variants of the denotation of the ruler, the same ethnonym, the Danes, is used (moreover the Danes figure as the object of protection), and the dominant motif is of conquering space. For Sigvatr, as for the creator of the Anglo-Saxon poem, the events serve as reason for glorification of the addressee of the poem. Just like Sigvatr's drápa and other skaldic panegyrics glorifying the addressee in connection with a concrete situation, the Anglo-Saxon poem is composed for the occasion: it is called to life by a concrete situation and concentrated on a single event. Of the many heroic deeds performed by Edmund, who had conquered Northumbria and Cumbria, only one, the reclamation of the Five Boroughs, was considered important enough to become the subject of poetry, because it restored the spatial wholeness of the realm. Like that of Knútsdrápa, the function of the Chronicle poem is to glorify the ruler by formally reconstructing space. The theme of the Anglo-Saxon poem, the glorification of a ruler in connection with a contemporary event, is close to the traditional subject of skaldic poetry, which also makes a ruler the object of praise. In contrast to other Old English heroic poems, which are narrative, orientated to the past, never (except for the Battle of Brunanburh and other Chronicle poems, such as the Coronation and the Death of Edgar, the Death of Alfred, the Death of Edward the Confessor) choosing as their subject a contemporary event, the Poem on the Five Boroughs is a proper panegyric to the King (encomium regis), and its main aim is to glorify him.

The shortness of the poem on the Five Boroughs is also uncharacteristic of Old English poetry, which often makes use of lengthy expanded scenes. Like asyndetic skaldic visas, the poem lacks explicit copulative coordination: the list of toponyms stands in isolation and is not syntactically connected either with the first sentence or with the second. The list of toponyms, similar to those in skaldic pulur, occupies five of the thirteen lines of the poem, leaving only eight whole lines (plus a refrain), reminding us of the skaldic visas consisting of eight lines.

Like a skaldic visa, the Anglo-Saxon poem consists of two parts which can be compared to skaldic helmings in which the poetic utterance finds its syntactic, semantic and formal completion. Whereas in skaldic helmings the communicative space is narrowed under the pressure of formal markers, the components of kennings, in the two parts of the Anglo-Saxon poem the communicative space is narrowed under the pressure of toponyms, ethnonyms, proper names and synonymic denotations of the ruler, functioning as substitutes for proper names.

The ring-composition of the poem on the Five Boroughs, containing a refrain which is unusual in Anglo-Saxon poetry, can be compared with the composition of a skaldic drápa, including a refrain (stef), which addressed the praise to the hero of the drápa and served as a guarantee of its effectiveness. A stef which is thematically close to the Anglo-Saxon poem can be found in Eyjólfr Daðaskáld's Bandadrápa, where a 'split refrain' (klofastef) or an 'extended refrain' (rekstef), is used, of which individual lines are incorporated as the fourth or last line of some stanzas:

\begin{tabular}{|c|c|c|}
\hline $\begin{array}{l}\text { Eyjólfr Daðaskáld } \\
\text { 'Bandadrápa' } \\
\text { (stef) (SkP I, } 462- \\
468 \text { ), Ólafs saga } \\
\text { Tryggvasonar 20, } 80\end{array}$ & $\begin{array}{l}\text { Dregr land at mun banda (line } 8 \text { of v. } \\
117 \ldots \\
\text { Eirekr und sik geira (line } 4 \text { of vv. } 149 \text {, } \\
\text { 152)... } \\
\text { veðrmildr ok semr hildi (line } 8 \text { of v. } 149 \text {, } \\
\text { 152)... } \\
\text { Gunnblíðr ok ræðr síðan (line } 4 \text { of vv. } \\
\text { 150, 153)... } \\
\text { Jarl goðvǫrðu hjarli (line } 8 \text { of vv. 150, } \\
153 \text { ) }\end{array}$ & $\begin{array}{l}\text { Wins land at the pleasure of the gods... } \\
\text { Eiríkr under himself of spears ... } \\
\text { Storm-generous and contrives warfare... } \\
\text { Rejoicing in battle and rules since then... } \\
\text { Jarl god-defended land. } \\
\text { (Trans. R.Poole) }\end{array}$ \\
\hline
\end{tabular}

In the Anglo-Saxon poem the function of the refrain is performed by the repetition of the proper name, Eadmund cyning, opening and ending the poem, the function of which is to concentrate praise on the hero of the poem. The effectiveness of the refrain is strengthened by the six uses of his panegyrical denotations, concentrated in symmetrical short lines, opening and closing the poem.

The piling up of names, reducing the narrative capacities of the poem, the omission of narrative details, the sudden transition from one action to the other (from 'went through' to 'set free') and the general compression, are compensated by the information contained in the prose context, which surrounds the poem and is devoted to linear narrative of the 
events. Like a skaldic visa, the poem on the Five Boroughs is hard to understand without prior knowledge of its theme, which required the inclusion of the historical context at the beginning of this report. Just as a skaldic visa exists as a quotation inside the prose text of a Kings' or a family saga, the poem on the Five Boroughs has come down to us inside the prose context of the Chronicle.

The fragmentary and anachronistic nature of the prose context could be accounted for by the probability that the compilers of the Chronicle meant to conceal or diminish the losses and defeats of the Wessex King. On the contrary, the significance of his victory is underlined by the poetic form of the quoted verse: under the influence of the poetic form, an isolated fact of reality is transformed into a poetic 'fact'. The poetic form of the Anglo-Saxon poem has the function which was specified in the definition of poetry in the Snorra Edda: 'What simple (non-periphrastic) terms are there for poetry? It is called poetry, glorifying song, eulogy, praise' (Hver eru ókennd nöfn skáldskaparins? Hann heitir bragr ok hróðr, óðr, marrð, lof). The formal organisation of the Anglo-Saxon poem is similar to the form of skaldic panegyrics and has a function close to magic: it immortalizes the praise, making it sacred.

A poem composed according to the model of skaldic panegyrics ensures the eternal glory of the object of praise, in the same way as a skaldic drápa. The minimising of narrative in the Anglo-Saxon poem is a consequence of its poetic effectiveness immortalizing praise. Poetic form is isolated here as a conscious artistic device acquiring new functional abilities and values: it reaches beyond contemporary record of a present fact, immortalising it and prospectively addressing it to posterity.

The poem on the Five Boroughs can be viewed as the Anglo-Saxon equivalent of Old Norse panegyric in its most ancient form, memorial drápa (erfikvaeði), to which, some scholars have suggested ${ }^{22}$, the roots of skaldic poetry can be traced. The tradition of eulogising living heroes and rulers in verse made possible the retention of the indigenous poetics of drápa, in particular its specific phraseology (kennings and heiti ${ }^{23}$ ), not directly naming and therefore not directly invoking the object of praise. It is possible to draw an analogy between the specific phraseology of drápa and the variations in the-denotations of the ruler in the Anglo-Saxon poem. The main function of the poem is similar to the aim of a skaldic panegyric - to sing praise to the ruler for his heroic deed, to immortalize him in human memory, to ensure eternal fame for the object of glorification. Thus whether or not the creator of the Anglo-Saxon panegyric, like a skald, was a "prince-pleaser"24 (to use Professor Stanley's denotation, whose motives, as he suggested, could have included "self-promotion") ${ }^{25}$, he must have been one of the first poets in Europe who elevated a single fact belonging to the contemporary present to the realm of high poetry, and thus earned the Anglo-Saxon King the nickname with which he entered posterity, Edmund the Magnificent (Edmundus magnificus), who reconstructed the spatial identity of his kingdom.

\section{Bibliography}

Arnold, Thomas, Symeonis monachi opera omnia, (1885), Rolls Series 75. London: Edward Arnold.

Batey, Collen, Clarke, Helen, Page, Raymond, Price, Neil, (1994), Cultural Atlas of the Viking World. Ed. James Graham-Campbell. Oxford: Andromeda.

Beaven, Murray, (1918), King Edmund I and the Danes of York. In: English Historical Review. Vol. 33, № 129.

Brooke, Christopher, (1979), The Saxon and Norman Kings. Glasgow: Fontana/Collins.

Dobbie, Elliott Van Kirk, ed., (1942). The Anglo-Saxon Minor Poems. Volume 6. The Anglo-Saxon Poetic Records. Ed. George Philipp Krapp and Elliott Van Kirk Dobbie. New York: Columbia University Press.

Earle, John, ed., (1885), Two of the Saxon Chronicles Parallel with Supplementary Extracts from the Others, Oxford: Clarendon Press.

22 Åke Ohlmarks. Till frågan om den fornnordiska skaldediktningens ursprung. Arkiv för nordisk filologi. Bd 5, 1944, 18-24.

${ }^{23}$ Detailed analysis of kennings and heiti in skaldic poetry is published in: Steblin-Kamenskii M.I. Skaldic Kenning (Skaldicheskii Kenning). In: Steblin-Kamenskii M.I. Historical Poetics (Istoricheskaya Poetika). Leningrad, 1978. P. 40-64; Gurevich E.A., Matyusina I.G. Skaldic Poetry (Poeziya Skaldov). Moscow: Russian State University for the Humanities, 2000. P. 21-71.

${ }^{24}$ Stanley E.G. A Thousand Years of English Political Poetry: A Limited Selection. Neophilologus, 2012. Vol. 96. P. 330.

${ }^{25}$ Stanley E.G. A Thousand Years of English Political Poetry: A Limited Selection. Neophilologus, 2012. Vol. 96. P. 330. 
Finnur Jónsson, Den norsk-islandske Skjaldedigtning, (1967-1973), B I-II. (Rettet text) København, 1912-1915. Rpt. København: Gyldendalske Boghandel Nordisk Forlag.

Skaldic Poetry of the Scandinavian Middle Ages: Vol. 1. Poetry from the Kings' Sagas: From Mythical Times to c. 1035, (2012), Edited by Diana Whaley. Turnhout: Brepols,; Vol. 2. Poetry from the Kings' Sagas: From c. 1035 to c. 1300, (2009), Edited by Kari Ellen Gade. Turnhout: Brepols; Vol. 3. Poetry from Treatises on Poetics, (2017), Edited by Kari Ellen Gade and Edith Marold. Turnhout: Brepols; Vol. 7. Poetry on Christian Subjects, (2007), Edited by Margaret Clunies Ross. Turnhout: Brepols; Vol. 8. Poetry in fornaldarsögur, (2017), Edited by Margaret Clunies Ross. Turnhout: Brepols.

Gurevich, E.A., Matyushina, I.G., (2000), Skaldic Poetry (Poeziya Skaldov), Moscow: Russian State University for the Humanities.

Harris, J., (1985), Die altenglische Heldendichtung. In: Europäisches Frühmettelalter. Klaus von See (Herausgeg.) Neues Handbuch der Literaturwissenschaft 6. Wiesbaden: Aula. S. 248-254.

Hollander, L., (1949), The Role of Verb in Skaldic Poetry. In: Acta Philologica Scandinavica 20, 267-276.

Lapidge, M., (1981), Some Latin Poems as Evidence for the reign of Athelstan. In: Anglo-Saxon England, 9, P. 61-98. Mawer, A., (1923), The Redemption of Five Boroughs. In: English Historical Review. Vol. 38. No. 152. P. 544-555.

O’Brien O'Keefe, Katherine, (1990), Visible Song: Transitional Literacy in Old English Verse, Cambridge: Cambridge University Press.

Ohlmarks, Åke, (1944), Till frågan om den fornnordiska skaldediktningens ursprung, Arkiv för nordisk filologi 57. P. 178-207.

Opland, J. (1980), Anglo-Saxon Oral Poetry: A Study of the Traditions. New Haven and London: Yale University Press.

Simeon of Durham. Historia regum Anglorum (sub anno 939). See Arnold, Thomas.

Smirnitskaya, O.A. (1994), Verse and Language of Medieval Germanic Poetry (Stikh i yazyk drevnegermanskoy poesii). Moscow: Moscow State University. In two volumes.

Smyth, Alfred, (1979), Scandinavian York and Dublin. The History and Archaeology of Two Related Viking Kingdoms. Vol. II, New Jersey and Dublin: Templekieran Press.

Stanley, E.G., (2012), A Thousand Years of English Political Poetry: A Limited Selection. Neophilologus. Vol. 96. P. 315-331.

Steblin-Kamenskii, M.I., (1978), Skaldic Kenning (Skaldicheskii Kenning). In: Steblin-Kamenskii M.I. Historical Poetics (Istoricheskaya Poetika). Leningrad: Leningrad University Press. P. 40-64.

Stenton, F., (1985), Anglo-Saxon England. Oxford: Oxford University Press. 